\title{
Immunohistochemical Expression of Matrix Metalloproteinases in Bile Duct Cancer Tissue
}

\author{
TAKENORI SAKAI \\ Department of Surgery, Kurume University School of Medicine, \\ Kurume 830-0011, Japan
}

\begin{abstract}
Summary: In the present study we have examined the immunohistochemical expression of matrix metalloproteinases (MMPs) in bile duct cancer tissue and the relationship between MMP expression and various clinicopathologic factors. We performed immunohistochemical studies of matrix metalloproteinase-2 (MMP2), and matrix metalloproteinase-3 (MMP3). MMP2 and MMP3 were expressed in $48.9 \%(23 / 47)$ and $44.7 \%(21 / 47)$ of the subjects, respectively. Subjects positive for MMP2 showed significantly higher association rates of MMP3 expression than those who were not $(p<0.05)$. MMP2 expression was also significantly higher in the group with histologically welldifferentiated lesions than in the group with poorly differentiated lesions $(p<0.05)$. Expression of MM2 and MM3 was significantly higher in subjects with neural invasion $(p<0.05)$. The MMP2-negative group had a significantly better prognosis than the MMP2-positive group $(p<0.05)$. MMP2 expression tended to increase as the degree of differentiation decreased, and this indicated a possibility that MMP2 and MMP3 may be involved in the development of perineural invasion in bile duct cancer. Perineural invasion is an important prognostic factor in bile duct cancer, and the fact that various types of cytokines are involved in the activation of MMPs suggested that bile duct cancer complicated by obstructive cholangitis might be associated with a poorer prognosis.
\end{abstract}

Key words bile duct cancer, matrix metalloproteinase, MMP2, MMP3, perineural invasion

\section{INTRODUCTION}

In many cases, bile duct cancers are already very advanced by the time they are discovered, and as a result a radical operation is often impossible. Even when curative resection is attempted, the rate of recurrence is high, and the prognosis of this disease is one of the poorest among all the gastrointestinal carcinomas. It is also known to have a high rate of complication with obstructive cholangitis.

Conventionally, as proposed by Liotta, the invasion and metastasis of cancer is thought to progress in three step theory, involving the basal membrane, adhesion factors, and matrix metalloproteinases (MMPs) [1]. In recent years there have been numerous reports on this subject with regard to gastric and colorectal cancers, however, there are few reports on malignant tumors in the biliary system, and the relationship between the basal membrane, adhesion factors, and MMPs in biliary system cancer has not been clarified [2-4]. In the present study, we examined the immunohistochemical staining expression of MMPs in bile duct cancer tissue, and examined the relationship between MMP expression and various clinicopathologic factors. 


\section{SUBJECTS AND METHODS}

\section{Subjects}

We studied 47 cases from which were extracted cases that were practicable from a clinicopathological study.

\section{Immunohistochemical studies}

We performed immunohistochemical studies of matrix metalloproteinase-2 (MMP2) and matrix metalloproteinase-3 (MMP3) (Fuji chemical). MMP2 is produced constantly by fibroblasts, and is considered to be activated by a signal originating from cancer cells. MMP2 is thought to be deeply involved in cancer invasion and metastasis.

MMP3 is often expressed in fibroblasts and cartilage cells and it is assumed that it is induced in ani- mal cells with a conspicuous malignant character.

\section{Staining methods}

Paraffin-embedding samples were sliced into $4 \mu \mathrm{m}$-thin sections and deparaffinization was performed according to normal procedures. Endogenous peroxidase activity was blocked during deparaffinization using 5\% hydrogen peroxide in methyl alcohol. Immunohistological staining was performed by the Envision method (Envision System high sensitivity, indirect measurement method, DAKO Japan).

\section{Evaluation of immunohistological expression}

We observed three places on the same specimen in a high-power field, and for both MMP2 and MMP3 expression was considered to be positive when positively stained cells covered $10 \%$ or more
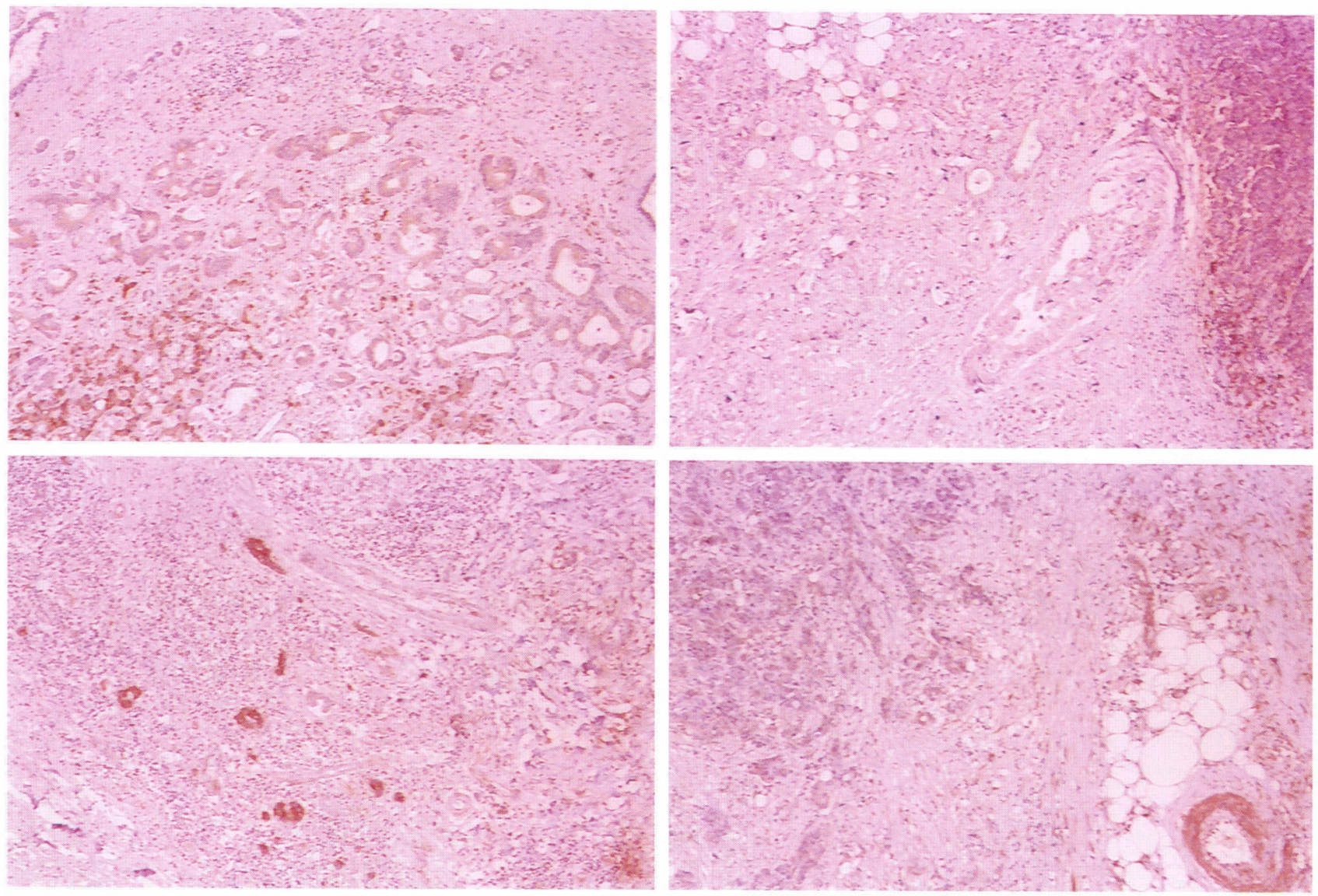

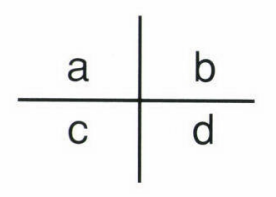

Fig. 1. The immunostaining of bile duct cancer tissue (Magnification $25 \times 10$ ). a (upper-left): MMP2 positive case. b (upper-right): MMP2 negative case. c (lower-left): MMP3 positive case. d (lower-right): MMP3 negative case. These photographs show that interstitial tissue and tumor cells were dyed by the anti-MMP2 and anti-MMP3 antibodies. 
of the observation area (Fig. 1).

\section{Statistical analysis}

We followed the General Rules for Surgical and Pathological Studies on Cancer of the Biliary Tract and performed a clinicopathological study that was accompanied by the presence of a macroscopic type, a histological type, a depth of invasion, a venous invasion, a lymph duct invasion, a perineural invasion, lymph node metastasis and liver metastasis. We classified the histopathological macroscopic type as $P$ type (a papillary type and an invasive papillary type), $\mathrm{N}$ type (a nodule type and an invasive nodule type), D type (diffuse infiltrating type), and histological type in a well differentiated group (a papillary adenocarcinoma and well-differentiated tubular adenocarcinoma) and a poorly differentiated group (moderately differentiated type and poorly-differentiated tubular adenocarcinoma) and studied them. We classified them into positive (more than 1) and negative $(0)$ groups with regard to venous invasion (v), lymph duct invasion (ly), perineural invasion (pn), lymph node metastasis (n) and liver metastasis. We used a chi-square test for the significance of differences associated with each factor, and used the Kaplan-Meier/Cox-Mantel test for the significance of differences associated with survival rate. A difference of $p<0.05$ was considered significant.

\section{RESULTS}

\section{Detailed breakdown of the subjects}

The 47 patients who were the subjects of this study consisted of 33 males and 14 females whose ages ranged from 33-77 years (mean age 34.3 \pm 8.9 years). The macroscopic findings were type $\mathrm{P}$ in 9 cases, type $\mathrm{N}$ in 23 cases, and type $\mathrm{D}$ in 15 cases (Table 1). The histological findings were papillary adenocarcinoma (pap) in 8 cases, well differentiated tubular adenocarcinoma (tub1) in 11 cases, moderately differentiated tubular adenocarcinoma (tub2) in

TABLE 1.

Macro- and microscopic type of the bile duct cancer tissue

\begin{tabular}{ccccc}
\hline & & \multicolumn{2}{c}{ Histological type } & total \\
\cline { 3 - 4 } & & $\begin{array}{c}\text { Well differentiated } \\
\text { groups }\end{array}$ & $\begin{array}{c}\text { Poorly differentiated } \\
\text { groups }\end{array}$ & \\
\hline $\begin{array}{c}\text { Macro- } \\
\text { scopic } \\
\text { type }\end{array}$ & P type & 7 & 2 & 9 \\
& N type & 9 & 14 & 23 \\
\hline & D type & 3 & 12 & 15 \\
\hline
\end{tabular}

TABLE 2.

Histological group of the bile duct cancer

\begin{tabular}{cccc}
\hline Histological group & cases & Histological type & cases \\
\hline $\begin{array}{c}\text { Well differentiated } \\
\text { group }\end{array}$ & 19 & Papillary adenocarcinoma & 8 \\
& & $\begin{array}{c}\text { Well differentiated tubullar } \\
\text { adenocarcinoma }\end{array}$ & 11 \\
$\begin{array}{c}\text { Poorly differentiated } \\
\text { group }\end{array}$ & 28 & $\begin{array}{c}\text { Moderately differentiated tubuller } \\
\text { adenocarcinoma }\end{array}$ & 23 \\
& & $\begin{array}{c}\text { Poorly differentiated tubuller } \\
\text { adenocarcinoma }\end{array}$ & 5 \\
\hline total & 47 & & 47 \\
\hline
\end{tabular}


23 cases, and poorly differentiated tubular adenocarcinoma (por) in 5 cases (Table 2).

\section{An expression of MMP 2 and $M M P 3$}

MMP2 was expressed in $48.9 \%$ (23/47) and MMP3 was expressed in $44.7 \%$ (21/47) of the subjects. Subjects positive for MMP2 showed significantly higher rates of MMP3 expression that those who were not $(\mathrm{p}<0.05)$ (Table 3).

Relation between MMP2 and MMP3 expression and the clinicopathologic factors

1) Relation between MMP2 and MMP3 expression and macroscopic/morphological type.

There was no clear correlation between MMP2 or MMP3 expression and macroscopic type.

2) Relation between MMP2 and MMP3 expression and histological type.

The case of positive MMP2 expression tended to be higher in subjects with poorly differen- tiated lesions. Positive MMP2 expression cases were significantly higher in the poorly differentiated group than in the well-differentiated group $(\mathrm{p}<0.05)$.

There was no significant difference in MMP3 expression in the histological type (Table 4).

3) Relation between MMP2 and MMP3 expression and histological depth of invasion.

There was no clear correlation seen between MMP2 or MMP3 expression and the histological depth of invasion (Table 5).

4) Relation between MMP2 and MMP3 expression and venous, lymph duct and perineural invasion (Table 6).

Positive expression case of MMP2 and MMP3 was significantly higher in subjects with perineural invasion positive cases $(\mathrm{p}<$ 0.05) (Table 7).

The presence or absence of venous or lymph duct invasion had no significant effect on MMP2 or MMP3 expression (Tables 8 and 9).

TABLE 3.

The correlation between MMP2 and MMP3 expressions

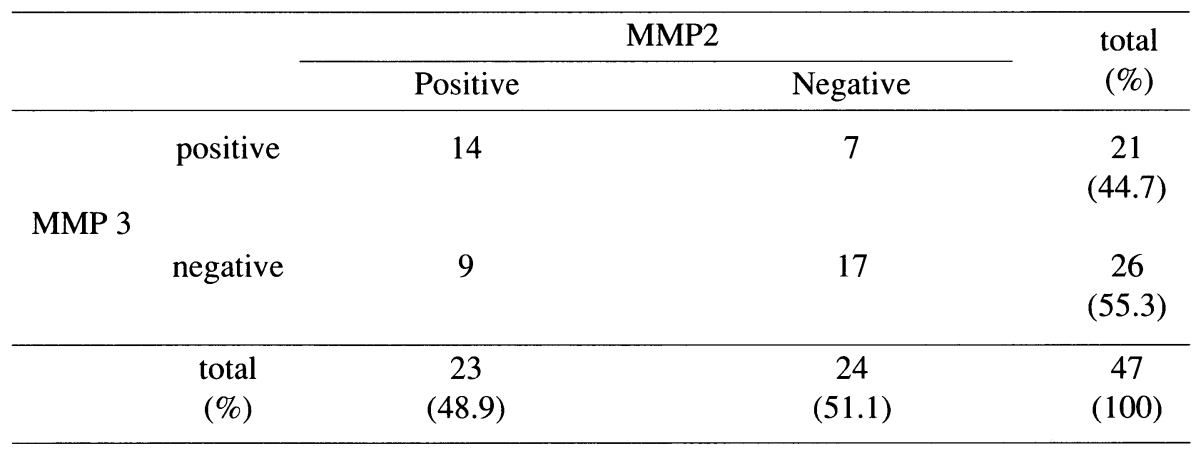

$\mathrm{p}=0.0415$

TABLE 4

Relation between histological group and MMP2/MMP3 expressions

\begin{tabular}{|c|c|c|c|c|}
\hline & \multicolumn{2}{|c|}{ MMP2 } & \multicolumn{2}{|c|}{ MMP3 } \\
\hline & $\begin{array}{l}\text { positive } \\
(\%)\end{array}$ & $\begin{array}{c}\text { negative } \\
(\%)\end{array}$ & $\begin{array}{c}\text { positive } \\
(\%)\end{array}$ & $\begin{array}{c}\text { negative } \\
(\%)\end{array}$ \\
\hline $\begin{array}{l}\text { Well differentiated } \\
\text { group }\end{array}$ & $\begin{array}{c}5 \\
(26.3)\end{array}$ & $\begin{array}{c}14 \\
(73.7)\end{array}$ & $\begin{array}{c}7 \\
(36.3)\end{array}$ & $\begin{array}{c}12 \\
(63.2)\end{array}$ \\
\hline $\begin{array}{l}\text { Poorly differentiated } \\
\text { group }\end{array}$ & $\begin{array}{c}18 \\
(64.3)\end{array}$ & $\begin{array}{c}10 \\
(25.7)\end{array}$ & $\begin{array}{c}14 \\
(50)\end{array}$ & $\begin{array}{c}14 \\
(50)\end{array}$ \\
\hline total & $\begin{array}{c}23 \\
(48.9)\end{array}$ & $\begin{array}{c}24 \\
(51.1)\end{array}$ & $\begin{array}{c}21 \\
(44.7)\end{array}$ & $\begin{array}{c}26 \\
(55.3)\end{array}$ \\
\hline
\end{tabular}


TABLE 5.

Relation between cancer invated depth and MMP2/MMP3 Expressions

\begin{tabular}{|c|c|c|c|c|c|c|c|}
\hline \multirow[b]{2}{*}{ group } & \multirow[b]{2}{*}{ number } & \multirow[b]{2}{*}{ depth } & \multirow[b]{2}{*}{ number } & \multicolumn{2}{|c|}{ MMP2 } & \multicolumn{2}{|c|}{ MMP3 } \\
\hline & & & & $\begin{array}{c}\text { positive } \\
(\%)\end{array}$ & $\begin{array}{c}\text { negative } \\
(\%)\end{array}$ & $\begin{array}{c}\text { positive } \\
(\%)\end{array}$ & $\begin{array}{c}\text { negative } \\
(\%)\end{array}$ \\
\hline $\mathrm{T} 1$ & 3 & $\begin{array}{l}\mathrm{m} \\
\mathrm{fm}\end{array}$ & $\begin{array}{l}1 \\
2\end{array}$ & $\begin{array}{c}1 \\
(33.3)\end{array}$ & $\begin{array}{c}2 \\
(66.7)\end{array}$ & $\begin{array}{c}1 \\
(33.3)\end{array}$ & $\begin{array}{c}2 \\
(66.7)\end{array}$ \\
\hline $\mathrm{T} 2$ & 13 & ss & 13 & $\begin{array}{c}6 \\
(46.2)\end{array}$ & $\begin{array}{c}7 \\
(53.8)\end{array}$ & $\begin{array}{c}6 \\
(46.2)\end{array}$ & $\begin{array}{c}7 \\
(53.8)\end{array}$ \\
\hline $\mathrm{T} 3$ & 31 & $\begin{array}{l}\mathrm{se} \\
\mathrm{si}\end{array}$ & $\begin{array}{l}18 \\
13\end{array}$ & $\begin{array}{c}46 \\
(51.6)\end{array}$ & $\begin{array}{c}15 \\
(48.4)\end{array}$ & $\begin{array}{c}14 \\
(45.2)\end{array}$ & $\begin{array}{c}17 \\
(54.8)\end{array}$ \\
\hline & & & & & & & \\
\hline
\end{tabular}

$\mathrm{m}$ : invasion is limited in mucosa fm: invasion is limited in fibrous muscularis ss: invasion reaches the subserosa se: invasion exposes in the serosal outside si: other organ invasion

TABLE 6.

Pathological factor of the bile duct cancer

\begin{tabular}{ccccc}
\hline Pathological factor & 0 & 1 & 2 & 3 or over 3 \\
\hline ly & 5 & 16 & 20 & 6 \\
& $(10.6)$ & $(34.0)$ & $(42.6)$ & $(12.8)$ \\
v & 12 & 19 & 13 & 1 \\
& $(25.5)$ & $(40.4)$ & $(27.7)$ & $(2.1)$ \\
pn & 12 & 4 & 18 & 13 \\
& $(25.5)$ & $(8.5)$ & $(38.3)$ & $(27.7)$ \\
n & 26 & 7 & 8 & 3 \\
& $(55.3)$ & $(14.9)$ & $(17.0)$ & $(6.4)$ \\
\hline
\end{tabular}

the upper: cases the lower: $(\%)$

TABLE 7.

Relation between perineural invasion and MMP2/MMP3 expressions

\begin{tabular}{|c|c|c|c|c|c|}
\hline & & \multicolumn{2}{|c|}{ MMP2 } & \multicolumn{2}{|c|}{ MMP3 } \\
\hline & & $\begin{array}{c}\text { positive } \\
(\%)\end{array}$ & $\begin{array}{c}\text { negative } \\
(\%)\end{array}$ & $\begin{array}{c}\text { positive } \\
(\%)\end{array}$ & $\begin{array}{c}\text { negative } \\
(\%)\end{array}$ \\
\hline \multirow[b]{2}{*}{$\mathrm{Pn}$} & $(+)$ & $21(60.0)$ & $14(40.0)$ & $20(57.1)$ & $15(42.9)$ \\
\hline & $(-)$ & $2(16.7)$ & $10(83.3)$ & $1(8.3)$ & $11(91.7)$ \\
\hline \multirow{2}{*}{\multicolumn{2}{|c|}{ total }} & $23(48.9)$ & $24(51.1)$ & $21(44.7)$ & $26(55.3)$ \\
\hline & & \multicolumn{2}{|c|}{$\mathrm{P}=0.0173$} & \multicolumn{2}{|c|}{$\mathrm{P}=0.0057$} \\
\hline
\end{tabular}


TABLE 8.

Relation between venous invasion and MMP2/MMP3 expressions

\begin{tabular}{|c|c|c|c|c|c|}
\hline & & \multicolumn{2}{|c|}{ MMP2 } & \multicolumn{2}{|c|}{ MMP3 } \\
\hline & & $\begin{array}{c}\text { positive } \\
(\%)\end{array}$ & $\begin{array}{c}\text { negative } \\
(\%)\end{array}$ & $\begin{array}{c}\text { positive } \\
(\%)\end{array}$ & $\begin{array}{c}\text { negative } \\
(\%)\end{array}$ \\
\hline \multirow{2}{*}{$\mathrm{v}$} & $(+)$ & $19(57.6)$ & $14(42.4)$ & $14(42.4)$ & $19(57.6)$ \\
\hline & $(-)$ & $3(25)$ & $9(75)$ & $5(41.7)$ & $7(58.3)$ \\
\hline \multirow{2}{*}{\multicolumn{2}{|c|}{ total }} & $22(48.9)$ & $23(51.1)$ & $19(42.2)$ & $26(57.8)$ \\
\hline & & \multicolumn{2}{|c|}{ ns } & \multicolumn{2}{|c|}{ ns } \\
\hline
\end{tabular}

TABLE 9.

Relation between lymph duct invasion and MMP2/MMP3 expressions

\begin{tabular}{|c|c|c|c|c|c|}
\hline & & \multicolumn{2}{|c|}{ MMP2 } & \multicolumn{2}{|c|}{ MMP3 } \\
\hline & & $\begin{array}{c}\text { positive } \\
(\%)\end{array}$ & $\begin{array}{c}\text { negative } \\
(\%)\end{array}$ & $\begin{array}{c}\text { positive } \\
(\%)\end{array}$ & $\begin{array}{c}\text { negative } \\
(\%)\end{array}$ \\
\hline \multirow{2}{*}{ ly } & $(+)$ & $22(52.4)$ & $20(47.6)$ & $20(47.6)$ & $22(52.4)$ \\
\hline & $(-)$ & $1(20)$ & $4(80)$ & $1(20)$ & $4(80)$ \\
\hline \multirow{2}{*}{\multicolumn{2}{|c|}{ total }} & $23(48.9)$ & $24(51.1)$ & $21(44.7)$ & $26(55.3)$ \\
\hline & & \multicolumn{2}{|c|}{ ns } & \multicolumn{2}{|c|}{ ns } \\
\hline
\end{tabular}

TABLE 10 .

Relation between lymph node metastasis and MMP2/MMP3 expressions

\begin{tabular}{|c|c|c|c|c|c|}
\hline & & \multicolumn{2}{|c|}{ MMP2 } & \multicolumn{2}{|c|}{ MMP3 } \\
\hline & & $\begin{array}{c}\text { positive } \\
(\%)\end{array}$ & $\begin{array}{c}\text { negative } \\
(\%)\end{array}$ & $\begin{array}{c}\text { positive } \\
(\%)\end{array}$ & $\begin{array}{c}\text { negative } \\
(\%)\end{array}$ \\
\hline \multirow{2}{*}{$\mathrm{n}$} & $(+)$ & $11(61.1)$ & 7 (38.9) & $10(55.6)$ & $8(44.4)$ \\
\hline & $(-)$ & $10(38.5)$ & $16(61.5)$ & $9(34.6)$ & $17(65.4)$ \\
\hline \multirow{2}{*}{\multicolumn{2}{|c|}{ total }} & $21(47.7)$ & $23(52.3)$ & $19(43.2)$ & $25(56.8)$ \\
\hline & & \multicolumn{2}{|c|}{ ns } & \multicolumn{2}{|c|}{ ns } \\
\hline
\end{tabular}

TABLE 11.

Relation between liver metastasis and MMP2/MMP3 expressions

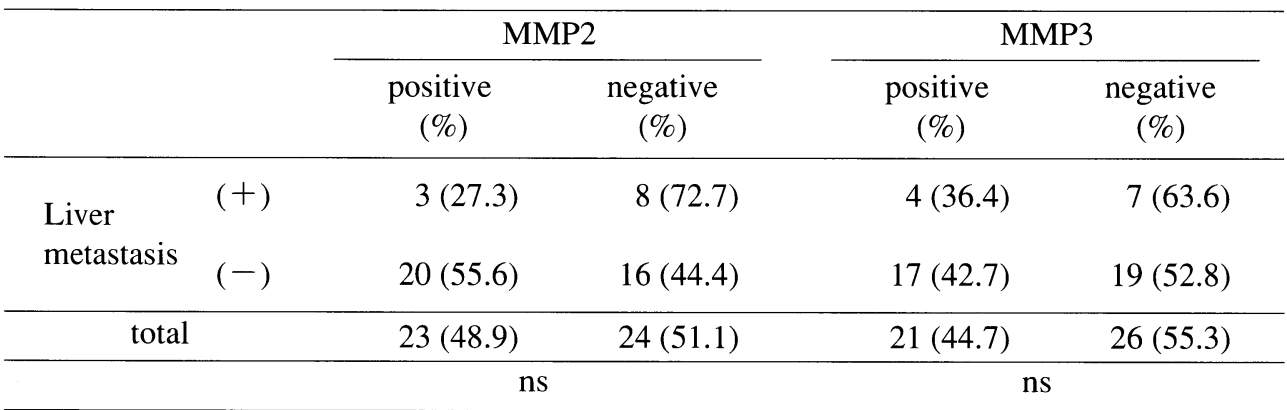


5) Relation between MMP2 and MMP3 expression and lymph node metastasis and liver metastasis.

Neither lymph node metastasis nor liver metastasis had any significant effect on the expression of MMP2 or MMP3 (Tables 10 and 11).

6) Prognostic significance of MMP2 and MMP3 expression.

We compared the cumulative survival rates between the subjects with and without MMP2 or MMP3 expression. The prognosis was significantly better in the MMP2 negative group than in the MMP2 positive group. With regard to MMP3, there was no significant difference in prognosis between the MMP3 positive and MMP3 negative groups (Figs 2- 4).

\section{DISCUSSION}

Invasion and metastasis in cancer progresses according to the following stages: 1) detachment of

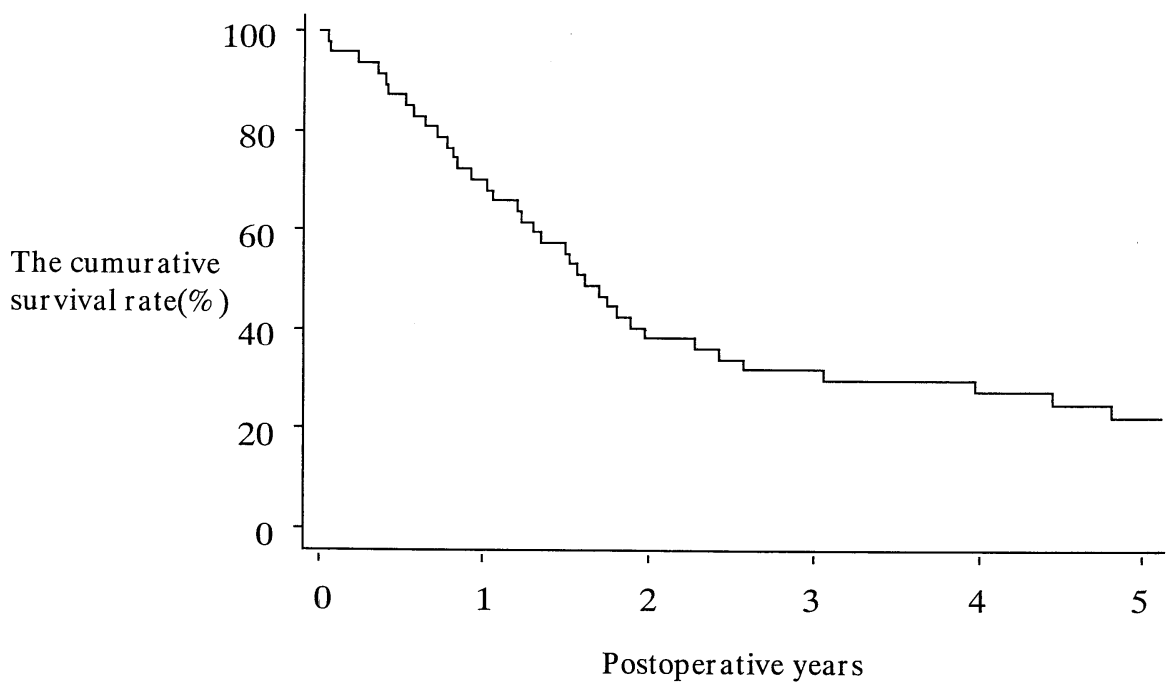

Fig. 2. Cumulative survival rate of the postoperative bile duct cancer (samples).

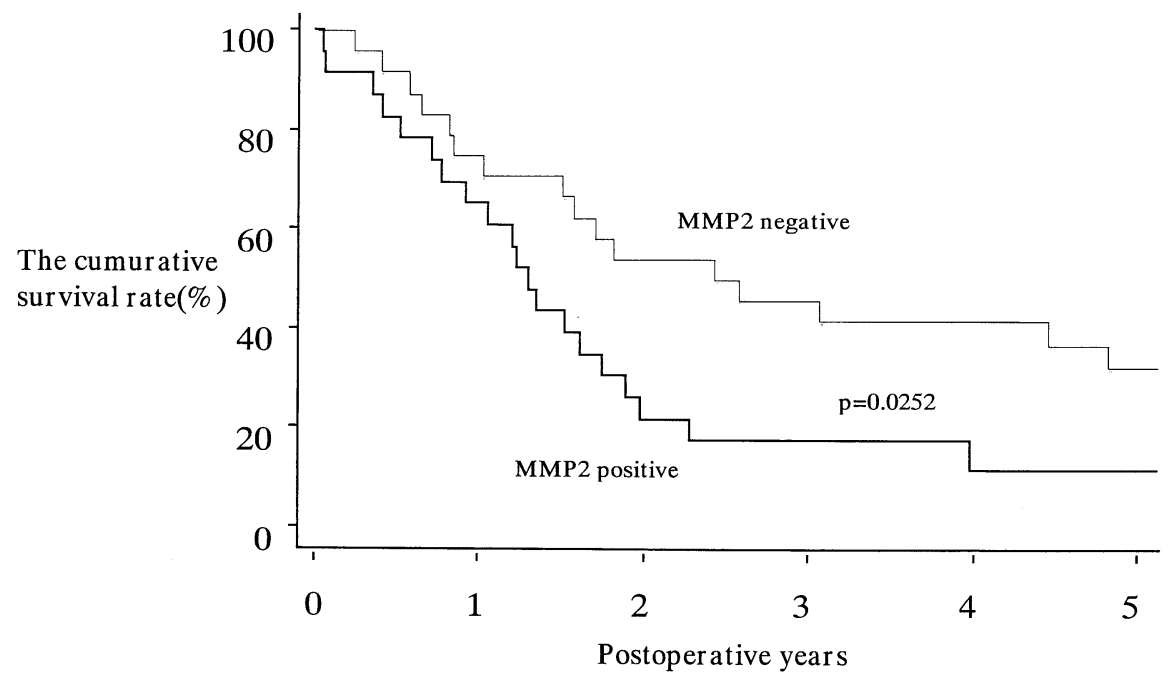

Fig. 3. Comparison of the cumulative survival rate of the postoperative bile duct cancer by MMP2 existence. 


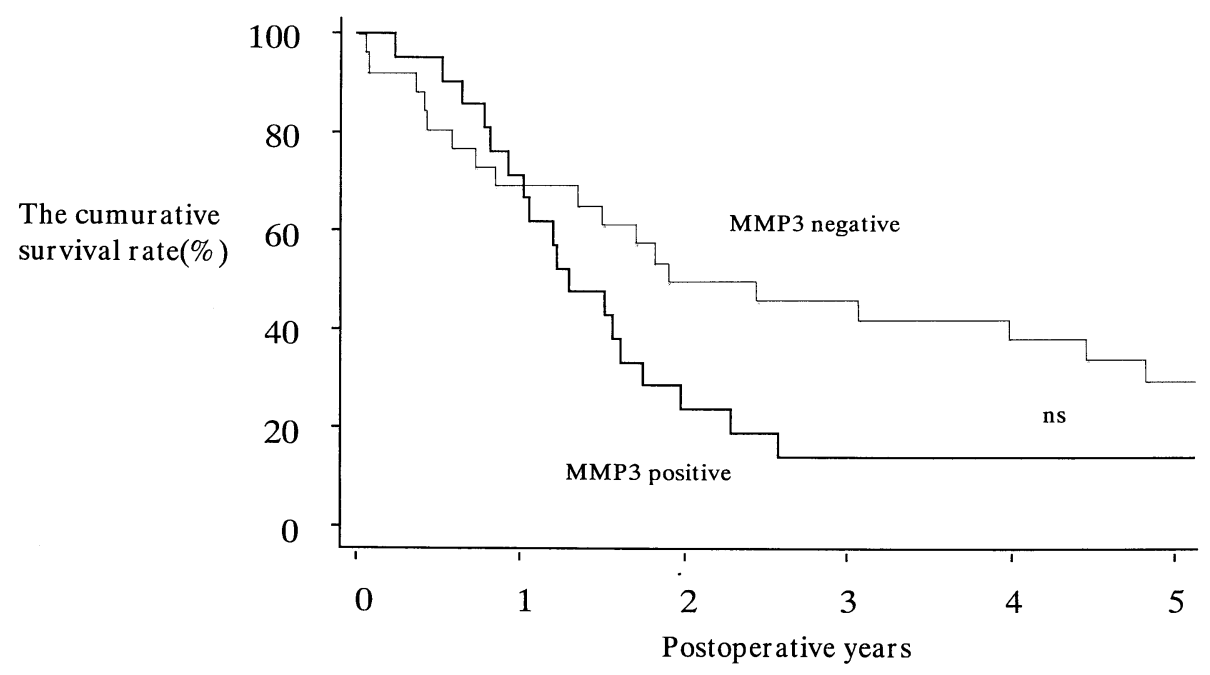

Fig. 4. Comparison of the cumulative survival rate of the postoperative bile duct cancer by MMP3 existence.

cancer cells from the primary tumor, 2) infiltration of the interstitial space by cancer cells, 3) attachment of cancer cells to the vascular endothelium, 4) degradation of the basal membrane, 5) intravascular infiltration by cancer cells, 6) evasion of immune mechanisms, 7) adhesion of cancer cells to the vascular endothelium of the target organ, and 8) invasion, establishment and proliferation of cancer cells in the blood vessel walls [6]. The extracellular matrix plays an important role at the beginning stage of this process of invasion and metastasis in cancer, and MMPs are enzymes that act to degrade the extracellular matrix. The MMP2 that we used in this study is known as gelatinase A or type IV collagenase and it actively degrades type IV collagen, which is the major component of the extracellular matrix [7]. In the same way as MMP9 (gelatinase B), which is another type IV collagenase, MMP2 is thought to be involved in the induction of invasion and metastasis by cancer tissues by degrading type IV collagen. MMP3 is known as stromlysin and is active in degrading fibronectin and laminin, which are also constituents of the extracellular matrix [8].

In the present study, we found that MMP2 expression was significantly higher when the degree of histodifferentiation was moderate or poor, indicating the likelihood that MMP2 expression increases as the degree of cellular differentiation decreases. No clear correlation was found between MMP3 expression and the degree of histodifferentiation, and we considered that MMP3 secretion is not related to the degree of cellular differentiation. Expressions of both MMP2 and MMP3 were significantly higher in subjects with nerve invasion, and this finding suggests that MMP2 and MMP3 are involved in the induction of nerve invasion in bile duct cancer. On the other hand, we found no clear correlation between MMP2 and MMP3 expression and venous or lymph duct invasion. This finding agrees with previous reports indicating that the mechanism of perineural invasion is independent from that of vein or lymph duct infiltration [9]. However, the detailed mechanism of nerve invasion remains to be clarified. It will be necessary to conduct further studies on the role of adhesion factors and nerve growth factors (glial cell line-derived neurotrophic factor: GDNF) $[10,11]$

Looking at cumulative survival, the prognosis was significantly better in the MMP2 negative group than in the MMP2 positive group. This finding indicates that the presence or absence of MMPs expression could be a useful prognostic indicator in bile duct cancer.

Various types of cytokines are involved in the secretion and activation of MMPs within tissues, and it is thought that trypsin and plasmin are especially important activators of MMPs. On the other hand, although trypsin and plasmin are effective in activating MMP3 they do not activate MMP2 precursors [12], so the existence of a trypsin $\rightarrow$ MMP3 $\rightarrow$ MMP2 cascade is suggested. Trypsin is secreted from cancer cells and from various other inflammatory cells. Bile duct cancer is associated with a high rate of compli- 
cation by obstructive cholangitis, so it is possible that trypsin secreted by induced inflammatory cells activates MMP3, which then activates MMP2, thereby promoting infiltration by cancer cells. It has previously been established that perineural invasion is an important prognostic indicator in bile duct cancer [13], and it is possible that the presence of cholangitis could be associated with a poorer prognosis because cholangitis is suspected to promote progression and perineural invasion in bile duct cancer.

ACKNOWLEDGMENTS: The author would like to thank Prof. Kinoshita and Dr. Imayama for their critical advice and suggestions.

\section{REFERENCES}

1. Liotta LA. Tumor Invasion and Metastasis - Role of the Extracellular Matrix: Rhoads Memorial Award Lecture'. Cancer Res 1986; 46:1-7.

2. Akagi Y. A Study on the Relation Between Liver Metastasis and Secretion of Matrix Metalloproteinase-2 and 9, Using the Liver Metastasis Model form Implanted Human Colon Carcinoma Cell in Nude Mice. J Jpn Soc Coloproctol 1994; 477:552-563.

3. Ishigami S, Arii S, Harada T, Mizumoto M, Mori A et al. The Different Expression of Metastasis Related Molecules in the Primary and Metastatic Tumors of Human Colorectal Cancer-Interrelationship between Cancer Cells and Stormal Tissues. Jpn J Gastroenterol Surg 1998; 31:984-989.

4. Nomura H, Fujimoto N, Seiki M, Mai M, and Okada Y. Enhanced Production of Matrix Metalloproteinases and Activation of Matrix Metalloproteinase 2 (Gelatinase A) in Human Gastric Carcinomas. Int J Cancer 1996; 69:9-
16.

5. General Rules for Surgical and Pathological Studies on Cancer of the Biliary Tract. September 1997 (The 4th Edition) Japanese Society of Biliary Surgery (JSBC).

6. Nicolson GL, and Poste G. Tumor implantation and invasion at metastatic sites. Int Rev Exp Pathol 1983; 25:77-81.

7. Okada Y, Morodomi T, Enghild JJ, Suzuki K, Yasui A et al. Matrix Metalloproteinase-2 from human Rhumatoid Synovial Fibroblasts: Purification and Activation of the Precursor and Enzymic Properties. Eur J Biochem 1990; 194:721-730

8. Umenishi F, Yasumitsu H, Ashida Y, Yamauti J, Umeda $M$ et al. Purification and Properties of Extracellular Matrix-Degranding Metalloproteinase Overproduced by Rous Sarcoma Virus-Transformed Rat Liver Cell line, and Its Identification as Transin. J Biochem 1990; 108:537-543

9. Takahashi S, Ogata Y, Miyazaki H, Maeda D, Murai S et al. Appraisal of Dissection of Nerve Plexuses around the Superior Mesenteric Artery for both Neural Invasion and Lymphnode Metastasis in Pancreatic Cancer. J Bil Panc 1991; 12:151-155.

10. Mochizuki Y. Mechanisms of Neural Invasion in Pancreatic Carcinoma. J JPN PANC SOC 1996; 11:293303.

11. Okada Y, Takeyama H, Satou M, and Manabe T. Neurotrophic Factor Dervied Invasion of Pancreatic Cancer. Jpn J Gastroenterol Surg 1998; 31:995-998.

12. Miyazaki K, Umenishi F, Funahashi K, Koshikawa N, Yasumitsu $\mathrm{H}$ et al. Activation TIMP-2/Progelatinase A Complex by Stromelysin. Biochem Biophy Res Commun 1992; 185:852-859.

13. Takahashi M, and Uchino J. Pathological Study on Perineural Invasion of Carcinoma of the Billiary TractIts Mechanisms and Models of Spread-. J Bil Panc 1991; 12:145-150. 